\title{
EIDOLOGICAL PRINCIPLES OF MODERN UKRAINIAN PROSE (LINGUISTIC ANALYSIS OF DARA KORNIY'S NOVELS)
}

\section{ЕЙДОЛОГІЧНІ ЗАСАДИ СУЧАСНОЇ УКРАЇНСЬКОЇ ПРОЗИ (МОВНИЙ АНАЛІЗ РОМАНІВ ДАРИ КОРНІЙ)}

\author{
Kaidash Alla ${ }^{1}$ \\ Homych Viktoria ${ }^{2}$
}

DOI: https://doi.org/10.30525/978-9934-571-78-7_29

\begin{abstract}
Eidology is interpreted as a branch of knowledge associated with the concepts of myths, symbols and images in the liberal arts studies. The essence of the myth as a semiotic system can be traced at the level of symbols and mythologems, which in the sign system of language are labeled as the names of the corresponding objects of extralinguistic reality. They also build a figurative system of author's linguistic speech. Myth has always been and is the object of scientific interest of philosophers, cultural instructors and linguists. The linguistic interpretation of the concepts of mythological consciousness at the level of artistic text structures is an extremely interesting direction in the development of modern language science. The study of the reproduction of the mythological characters' essence in the writer's linguistics is an urgent aspect of linguistic analysis of artistic speech and linguistic-stylistic research. The novelty of this work is in the investigation of the mythological vocabulary used in the novels of the Ukrainian writer Dara Korniy. The purpose of the article is the semantic and functional analysis of mythological nominations selected from the works of contemporary Ukrainian literature. The achievement of this goal involves solving the following main tasks: 1) to establish the essence of the «myth» concept giving examples of foreign and Ukrainian scholars' approaches; 2) to carry out a comparative analysis of the general theoretical interpretation of the objects of mythological reality and the individual-
\end{abstract}

\footnotetext{
${ }^{1}$ Candidate of Philological Sciences, Associate Professor at the Department of Ukrainian Language,

Nizhyn Mykola Gogol State University, Ukraine

${ }^{2}$ Candidate of Philological Sciences, Associate Professor at the Department of Social-Humanitarian Disciplines,

NULES of Ukraine «Nizhin Agrotechnical Institute», Ukraine
} 
author's interpretation of the declared mythological concepts in the artistic speech; 3) to trace the linguistic specificity of the mythological nominations used in the writer's language. The object of the study is mythological vocabulary as one of the microsystems of the Ukrainian literary language. The subject of scientific analysis is the semantic and functional peculiarities of the mythological nominations used in contemporary Ukrainian prose. The nature of the study leads to the need of usage a descriptive method (with its techniques): a) external interpretation means the description of the connection with extralinguistic phenomena; b) sociological explains the definition of thematic groups; c) logical-psychological is a research of the correlation of language means with the concepts of mythological reality; a structural method (with its techniques): a) component analysis requires the division of the semantics of linguistic units into seven groups; b) distributive analysis is in the examination of the specifics of the usage of myth nominations in the artistic speech); comparative method investigates the definition of common and distinctive features of the studied mythological nominations in the visual interpretation and individual author's interpretation. A myth is a multifaceted phenomenon which scholars explain paying attention on various aspects of the manifestation of his essence. The objects of mythological consciousness of ancient Ukrainians include nominations for the designation of gods and deities, mythological creatures, plants, animals, speeches, abstract concepts. The official pantheon of Old Slavic mythology represents masculine and feminine images. Some of them are presented in the novels of the writer making up a multifaceted system of descriptive creation. The mythological basis of ancient folk ideas and beliefs has gained an author's interpretation in the artistic speech of Dara Korniy. The author retains the fundamental concept of the mythology of the ancient Slavs and expanded the semanticfunctional field of mythological nominations.

\section{1. Вступ}

У гуманітарних науках ейдологія тлумачиться як галузь знань, пов'язана з поняттями міфів, символів, образів. Сутність міфу як семіологічної системи простежується на рівні символів, міфологем, що в знаковій системі мови маркуються як номени відповідних об'єктів екстралінгвальної реальності, а в художньому мовленні формують образну систему авторського мовосвіту. 
Міф становив і становить об'єкт наукових зацікавлень філософів (К. Леві-Строс, 3. Фройд, О. Лосєв, С. Токарев та ін.), культурологів (О. Афанасьєв, Є. Мелетинський, М.Попович, Б. Рибаков, Ю. Павленко та ін.), мовознавців (О. Потебня, В. Іванов, В. Топоров, Н. Слухай та ін.).

Цікавим напрямком у розвитку сучасної науки про мову є лінгвальна інтерпретація концептів міфологічної свідомості на рівні художніх текстових структур. Вивчення специфіки відтворення сутності міфологічних персонажів у мовосвіті письменника $є$ актуальним аспектом лінгвістичного аналізу художнього тексту, лінгвостилістичних досліджень. Новизна пропонованої розвідки полягає в тому, що в ній обстежено міфологічну лексику, уживану у творах української письменниці Дари Корній.

Метою статті є семантичний і функціональний аналіз міфологічних номінацій, дібраних із творів сучасної української літератури. Досягнення поставленої мети передбачає розв'язання таких основних завдань: 1) обгрунтувати сутність поняття «міф» на прикладі концепцій зарубіжних та українських учених; 2) здійснити порівняльний аналіз загальнотеоретичного тлумачення об'єктів міфологічної дійсності та індивідуально-авторської інтерпретації заявлених міфоконцептів у художньому мовленні; 3) простежити лінгвостилістичну специфіку вживання міфологічних номінацій у мовосвіті письменниці.

Об'єктом пропонованого дослідження є міфологічна лексика як одна $з$ мікросистем української літературної мови; предмет наукового аналізу становлять семантичні й функціональні особливості міфологічних номінацій, уживаних у сучасній українській прозі.

Характер дослідження зумовлює необхідність використання таких методів, як описовий (із його прийомами: а) зовнішньої інтерпретації - у характеристиці зв'язку з екстралінгвальними явищами; б) соціологічним - у визначенні тематичних груп; в) логіко-психологічним у дослідженні співвіднесеності мовних засобів із концептами міфологічної дійсності); структурний (із його методиками: а) компонентного аналізу - у розщепленні семантики лінгвальних одиниць на семи; б) дистрибутивного аналізу - в обстеженні специфіки вживання міфоназв у художньому контексті); порівняльний - у визначенні спільних і відмінних ознак досліджуваних міфологічних номінацій в узуальному тлумаченні й індивідуально-авторській інтерпретації. 


\section{2. Теоретичне підгрунтя поняття «міф»}

«Міфологічні уявлення давніх українців виступають протягом значного історичного відтинку часу домінантою духовного життя народу і $є$ грунтом для розвитку духовної національної культури. Міф кодифікує народні вірування, звичаї, правила культурного співжиття. Міфотворчість варто розглядати не лише як найдавнішу форму розвитку людської думки, а й як своєрідну символічну «метамову», у термінах якої людина моделює, структурує та інтерпретує світ» [2, с. 18]. Міф - це багатогранний феномен, у тлумаченні якого вчені акцентують на різних аспектах вияву його сутності. Так, Р. Барт трактує міф як особливу (семіологічну) систему, специфіка якої полягає у його створенні на основі послідовності знаків за допомогою мови. Тому міф учений визначає вторинною системою, що має символічність та опосередкованість.

Загальні архетипні корені в колективному несвідомому людства вбачав К.Г. Юнг. К. Кереньї акцентував на таких аспектах міфології, як осмисленість, живописність і музикальність. Міф як одну з реальностей культури тлумачить М. Еліаде. Учений твердить, що в міфології відображено минуле, позначене процесом творення, виникнення, що сприяє сакралізації міфів.

М. Стеблін-Каменський розглядав міфи як образи, що закріпилися в слові. О. Лосєв убачав безпосередній зв'язок між буттям і свідомістю. На його думку, міфологічна свідомість формує уявлення про об'єкти міфобуття, яке осмислюється людиною. Є. Мелетинський пов'язував міф зі створенням вищої реальності, яка сприймається як архетип життєвих форм.

Вивченням сутності поняття міфу активно займалися й українські письменники XIX ст. Так, М. Костомаров розглядав формування міфологічного світогляду давніх слов'ян за антропологічним принципом, тобто, на думку вченого, в уявленні давньої людини природа олюднювалася, а тому явища навколишнього світу ототожнювалися 3 людською сутністю. При цьому людина усвідомлювала вищість і всемогутність сил природи. Домінантним принципом давньослов'янського світогляду науковець називав світлопоклоніння [14, с. 202]. Ідея світла реалізується на пантеїстичному рівні давньослов'янського міфологічного світогляду $[14$, с. 208]. Процес творення світу М. Костомаров пов'язував з образом Лади - всетворної любові [14, с. 221]. 
Така думка про створення світу за допомогою премудрої любові Лади простежується й у міфологічній концепції Я. Головацького. Дослідник зауважував, що світ «оживотворений вогнецвітом, духом краси, гармонії та розуму» [3, с. 44]. На думку письменника, в основі творення світу знаходилася взаємодія чоловічого (утіленням якого $\epsilon$ світло) і жіночого начала (представлене водною стихією).

На ключовій ролі води в процесі світотворення наголошував I. Нечуй-Левицький. На його думку, першопочатково існувало море 3 двома дубами [17, с. 74]. Із процесом творення всесвіту пов'язані атмосферні, солярно-лунарні й геоморфні образи [17]. Письменник дотримувався традиційного погляду на пантеїстичний і пандемонологічний рівні давньослов'янської міфологічної системи, але диференціював їх.

Опрацьовуваши зібраний фольклорний матеріал, Б. Грінченко підтвердив думку про домінантну роль стихій природи в міфологічних поглядах давніх слов'ян. Серед представників міфобуття письменник виокремив надприродні істоти, небіжчиків і людей із чудесною силою.

На основі народних вірувань, уявлень і повір’їв власну міфологічну концепцію сформулював П. Куліш. Пильну увагу письменник приділив фауністичним образам і пов'язаним із ними процесом метаморфоз (перетворення у вовкулаку, сирен, дятла, зозулю, солов'я тощо [7].

Значну увагу зооморфним міфоістотам приділив також М. Драгоманов. Дослідник описав велику кількість фауністичних міфообразів, схарактеризував повір'я, пов'язані із цими міфоконцептами, описав метаморфози, у яких задіяні відповідні персонажі [6].

В. Гнатюк виділив три основні групи міфологічних персонажів: боги, нижчі божества та демони, люди з надприродною силою [5]. Окремим типом дослідник виділив архетипні міфологеми, які він назвав персоніфікаціями через їхню одухотвореність.

Формування міфологічного світогляду давніх слов'ян О. Потебня пов'язував із пізнавальним процесом: «Міфічний образ - не вигадка, не свідомо довільна комбінація наявних даних, а таке їх поєднання, яке здається найбільш вірогідним дійсності. Міф може бути засвоєний народом лише тому, що він заповнює прогалини в системі знань» [21, с. 483].

Отже, представлені міфологічні концепції свідчать про зацікавленість дослідників проблемами опису міфобуття як складника духовно-культурного розвитку нації. 


\section{Chapter «Philological sciences»}

\section{3. Опис міфологічної лексики \\ в концепціях українських лінгвістів}

Міфологічні уявлення та вірування давніх українців засвоювалися на вербальному рівні, відтак слово постає мовомисленнєвим центром міфологічної концепції. О. Афанасьєв наполягав, що «слово і міф на початку свого доісторичного творення тісно пов'язуються між собою, взаємно діючи один на одного. Якщо міф нерідко зумовлює створення цілого ряду поетичних сказань, ... то, з іншого боку, живе слово ... також часто зумовлює формування деяких міфічних уявлень» [1, c. 201].

На основі фольклорних текстів досліджував міфологічні образи О. Потебня. Учений акцентував на ідеї світла, із якою пов'язана вся лексична мікросистема міфологічної концепції: «Якби ми не знали, що божества вогню та світла займали важливе місце в язичницьких віруваннях слов'ян, то могли б переконатися в цьому за великою кількістю слів, які мають у своїй основі уявлення про вогонь і світло» [20, с. 7].

I. Огієнко виділив онімні найменування головних богів давньослов'янського міфосвітогляду й апелятивно-збірні назви другорядних богів і божеств. Крім того, на мовному рівні дослідник визначив таку особливість: «Для багатьох цих божків наші предки так і не склали назви, бо не глибоко персоніфікували їх» [16, с. 85].

I. Желєзняк до міфологічної лексики зараховує власні назви, «найменування вигаданого суб'єкта або об'єкта в переказах, казках, міфах тощо» [25, с. 318]. У межах онімної системи міфономінації розглядають також Н. Колесник [10, с. 30], Н. Подольська, виділяючи міфоантропоніми, міфотопоніми, міфоперсоніми, міфофітоніми та міфозооніми [19, с. 124-125].

Ширше коло міфологем визначає Н. Слухай-Молотаєва, яка на прикладі творів Т. Шевченка аналізує міфологеми, що є першоелементами буття (вогонь, вода, земля, повітря), астральні, вегетативні, орнітальні міфологеми [24]. Т. Лукінова також розглядає лексичну мікросистему мови, що відображає давні уявлення та вірування, пов'язані з рослинами, тваринами тощо $[15$, с. 60$]$. Детальну класифікацію східнокарпатської міфологічної лексики здійснив Б. Кобилянський [9].

Формування міфологічної мікросистеми лексичного складу сучасної української літературної мови позначене тенденцією до розширення кола лексем відповідного семантичного спрямування. 


\section{4. Семантико-функціональна інтерпретація пантеїстичних номінацій}

Офіційний пантеон давньослов'янської міфології представляють маскулінні та фемінні образи. Закономірною є кількісна перевага чоловічих персонажів, оскільки «у первісному патріархальному середовищі і в умовах дружинного ладу й державності, коли влада належала чоловікам, первинне жіноче божество втрачало своє головне становище і в генеалогії, і в чинній системі релігійних уявлень» [22, с. 358]. Тому очолює пантеон Род-Сварог, образ якого пов'язаний із культом земного вогню. Жіночим образом виступає богиня Мокоша. Як зазначають В. Іванов і В. Топоров, «для найдавніших джерел жіноча природа Мокоші випливає із граматичної форми іiі назви і частково з того факту, що Мокоша звичайно закінчує список богів» [8, с. 19].

Дара Корній ці два образи давньослов'янської міфології об'єднує в подружню пару. На вербальному рівні письменниця утворює синонімічні ряди онімів: Земун - Рожаниця - Мокоша - Праматір; Сварог Род - Птах - Сокіл - Прабатько. У романі «Зворотний бік темряви» авторка розмежовує функції Сварога й Рода: «Сварог наш творецьь, а Род - батько неврів» [13, с. 165] (неври - жителі Невридії, що знаходиться у світі Білих Вурдалаків). Описуючи цей світ, письменниця згадує про поклоніння та жертвоприношення богам: «Поклонялися тут і Сварогу, але найбільше шанували та поважали Рода та Берегиню Рожсаницю. Їх жертовники стояли посеред Милограда. Й усі його мешканиі - старі, дорослі, малі - починали та закінчували свій день біля капища в молитві. Усе робилося мовчки, кожен просив про своє, кладучи на жертовний камінь те, що вважав достойним богів, які мали охороняти та оберігати роди. Лісові ягоди, гриби, мед, віночки з трав, букети лісових квітів» [13, с. 165].

Сутність образу Рода Дара Корній яскраво передає в молитві до нього, укладеної в уста Мирослада в романі «Зворотний бік світів»: «-Роде Всевишній, Ти тримаєш у собі все суще і несуще, усе видиме $і$ невидиме, Ти - Правда і Добро, Любов і Справедливість. Велика милість Твоя, Ти праведників винагороджуєш, Ти кривдників милуєш, заблукалих рятуєш, життям нашим опікуючись через Богів Рідних! Це Ти призначив нам закони Правди через життя явне пізнати, випробування долаючи, душу шляхетною працею освячувати, рідних любити, по Правді жити, илях свій честю засівати, щубб Слава проростала!» [11, с. 90]. 
Образи головних богів давньоукраїнського пантеону в мовосвіті письменниці марковані національною символікою: “Дерев'яні фігури батька Рода та Матері Рожсаниці мали на головах вінки з хрещатого барвінку та любистку» [11, с. 87]. Ідол Рожаниці авторка змальовує так: «Рожаниця тримала над собою підняті до неба руки. У кожній долоні-запалена свіча. На долонях Праматері були ті ж самі знаки, щуо й на чарі Рода. Праматір тримала вогонь земний, піднімаючи його вгору, ближче до вогню небесного» [11, с. 87-88].

3 образом Праматері письменниця пов'язує створення галактики Молочний Шлях: «Молочна дорога, яку, за легендою, створила Праматір Земун, коли випадково вилила на чорний оксамит ночі молоко, мирно тримала у своїх обіймах Усесвіт» [11, с. 9].

На думку Ю. Павленка, «Сварог втілював ідею порядку, справедливості, ієрархії, гармонії Космосу» [164, с. 113]. І. Огієнко зазначав: «Сам Сварог спочиває, а світом правлять його діти, Сварожичі» $[16$, с. 96]. Уособлюючи небесну гармонію та впорядкованість світу, Сварог протиставляється Хаосу, що визначається як «темний, небезпечний, невпорядкований світ навколо структурованого Всесвіту. Імовірно, з ним пов'язувався образ Стрибога та його породжень-синів, зокрема таких, як буремні вітри» [18, с. 114-115].

У мовосвіті Дари Корній Стрибог є одним із центральних персонажів. Негативне сприйняття цього образу пов'язане з чорним кольором: «Коли дивилася, як Стрибог огортав себе люттю у ї̈ спальні, перед тим як вдарити Птаху, не просто боялася: бачила більше, аніж хотілося, - чорноту в його голові, руках, сериі» [13, с. 13]. Цей колір представлений і в портретній деталі: «Дивилася пильно в його чорні, бездонні, як вода у ріųi, очі» [13, с. 20]. Зв'язок із темним світом авторка підкреслює в контекстах: «Зрештою, усім відомо, щзо Стрибог ніколи не був світлим. Рано чи пізно його справжня сутність вилізла б нагору, бо, скільки вовка не годуй, він усе одно до лісу втече» [13, с. 52]; «Тому дивну любов Стриба до вбивства безпомічних тварин, яку не поділяла й Птаха, списував на той темний бік у душі господаря, який мусив якось проявлятися» [13, с. 142]. Великий темний безсмертний Стрибог у романі «Зворотний бік темряви» постає персонажем, якому властиві всі риси й почуття звичайної смертної людини: «Стрибог ошелешено дивився на Мальву, аж рота від несподіванки відкрив. Через те нагадував не жорстокого та сильного бога, а розгубленого хлопчика, якого 
спіймали на гарячому» [13, с. 17]. Мати Стрибога Мара називає його недолугим сином-телепнем [13, с. 34]. Життєву таємницю Стрибога розкриває Птаха: «Володарка Смерті Мара - мати Стрибога $i$, звісно, дружина Мора. Вона залишила його в світі темних зовсім крихітним. Пам'ять дитині заблокували, $і$ Стрибог донедавна вважав, щэо його мати померла, народжуючи його» $[13$, с. 54]. Та в образі великого Стрибога письменниця підкреслює й світлий бік: «Стрибог $i$ сам не розумів до кіния, щзо відбувається з його душею. Отою безсмертною, отою чорно-пречорною. Ніяка вона не чорна, як би там батько не старався його, а ще більше себе, в изьому переконати чи навертати, ставити обличчям до безодні. Це була вже не душа того страшного та жорстокого Стрибога, котрий колись не знав Птахи, який ще не вмів кохати, мав серие замкнутим, запечатаним» [13, с. 180].

Богами Середнього світу в давньоукраїнській міфології Ю. Павленко визначає Дажбога, Перуна, Вогня-Сварожича, Ладу. Дажбог відповідав за впорядковане, мирне й безпечне життя, дбав про суспільний лад і контролював сільськогосподарську діяльність. У художньому мовленні Дари Корній він згадується як син Місяцівни: «Тутешній люд вважає Місяиівну матір'ю Дажбога» [11, с. 18]. У міфологічній свідомості давніх слов'ян Дажбог уявлявся богом Сонця та пов'язувався з іншими образами. На цей зв'язок указує Ю. Павленко: «... сонячний Дажбог (Дажбог-Хорс) ... виступав у трьох сезонних іпостасях (Коляди, Лада / Ярила, Купайла) і через них співвідносився 3 двома провідними богинями кохання і родючості - весняною Ладою (яка асоціювалася з пробудженням природи, ії квітінням, оплідненням) та літньою Мокошею, пізнішою Мареною (яка асоціювалася з урожаєм, що вже майже визрів і який незабаром потрібно буде збирати)» [18, с. 267].

У підпорядкуванні Перуна були війни. Перун виконував функцію бога дружини, тому його атрибутами дослідники називають зброю, грім і блискавку: «Очі Перуна метали блискавки, які прошивали розум та серие» [11, с. 167]; «I тоді на блискучій колісниці, запряженій трійкою баских коней, з'явився він-могутній і сильний. Він промчав, наче буревій небом, за спиною замість крил мав сагайдак зі стрілами та перекинутий через плече лук, а у кожній руці по мечу. I коли меч торкався меча, з нього вилітали смертельні блискавиці. І кожна з них завжди влучала в иіль. Син Сварога, блакитноокий, русявий, з мечами, які викував у небесній кузні спецііально для сина батько й омила божою 


\section{Chapter «Philological sciences»}

росою мати Мокоша, прибув якраз вчасно» [12, с. 41]. Це зумовлює локалізацію Перуна: він перебуває на небі. Таку особливість відтворює художній контекст: "Адже сили до Перуна повернулися, $i$ він зараз уміло та впевнено керував стихіями в небі» [11, с. 89]. Невід'ємним атрибутом міфообразу Перуна є стріла. Цей об'єкт міфологічної дійсності набуває яскраво вираженої концептуальної спрямованості, отримуючи індивідуальну кодифікацію на вербальному рівні. Так, стріла Перуна називається стожаром. У художньому мовленні Дари Корній цей міфоконцепт наділений магічними властивостями: « $\boldsymbol{C m p i -}$ ли Перуна - могутні, але й небезпечні. Вони можуть повертати до життя иілі світи, а можуть вбити миттєво, навіть безсмертного» [12, с. 116-117]; «Незвично потужна зброя. Вона легко долає всі перешкоди у вигляді закляття, замовляння, будь-яку магію розбиває на друзки - i темну, і світлу, $і$ навіть сіру. Вона завжди втрапляє в иіль, $i$ майже миттєво вбиває того, на чию смерть замовлена» [12, с. 271].

Фемінний образ Лади в давньоукраїнській міфології наділений функцією відтворення життєвих сил людини й природи. У романі «Зворотний бік світів» Лада $\epsilon$ повелителькою любові. У творі визначено іiі сімейний статус: вона - дружина Перуна й мати його трьох дітей. У мовосвіті Дари Корній цей образ національно маркований: «I за таку любов до калини, $i$ за красу, звісно, Перун свою дружину Ладу ніжно називає дівчина-калина» [11, с. 25].

Від шлюбу Лади й Перуна народилося троє дітей - сини Лель і Полель і донька Леля. У романі «Зворотний бік світів» брати постають хлопчиками-бешкетниками, які прагнуть пригод і рятують Мальву.

Фемінними образами міфологічного світогляду Дара Корній називає ще Лідницю (це «жінка з крижаними очима та крижаним обличчям, дмухала таким холодом, щуо навіть повітря довкола, здавалося, замерзало» $[12$, с. 40]), Вогнявицю (безжальну та жорстоку старшу доньку Чорнобога: «П̈̈ темна магія могла вбивати найсильніших, навіть богів, і жодні світлі сили не мали моці тому противитися» [12, с. 41]); Лелю (схожу «на матір зовні й на батька внутрішньо... Скільки чоловічих сердець вона розбила? Володарка весни й краси має бути такою. Вродливою та сильною» [12, с. 206]).

Традиційно в ідіолекті Дари Корній тлумачиться образ Ярила - весняного сонця [13, с. 149]: «Наречений Лелі - ие син самого Дажбога, онук Білобога. Ярило Прекрасний. Небесний войн, який визволяє 
землю від стужі та холоду, розчищає дорогу для приходу Весни-Лелі, відмикає сонячними ключами небесну браму для благодатних роси та дощів. Ярило і був таким - ярим, весняним, юним, сердитим, гарячим, пристрасним» [13, с. 232]. Його функційна спрямованість широка: він - «бог війни та любові; міфологічний і ритуальний персонаж, пов'язаний $з$ ідеєю родючості, в першу чергу весняної. Ярило бог-Сонце весняного рівнодення, бог молодого кохання та парування; бог любовних пристрастей. Розквіту природи та дітонародження» [4, с. 614]. Цю метасемантику образу підкреслено й у художньому мовленні письменниці: "То символ чистого весняного сонячного світла, символ Ярила-Сонця. Символ багатства та доброго врожаю. Символ ярої сили та ярої любові» [12, с. 230]. Уживані атрибутиви, морфемно пов'язані з коренем імені персонажа, пояснюють значення міфообразу: «Корінь «яр» поєднує в собі: світло й тепло; юні, стрімкі, до нестями збуджені почуття; любовні пристрасті й родючість: поняття, нерозривні з уявленнями весни та ії̈ грозових явищ» [4, с. 614]. Образ Ярила корелює з фемінним образом Лелі, яка теж пов'язана з весною: «Отак у світи смертних приходила весна. Леля торкалася долонями землі - і та оживала, Леля дмухала на ліси - $і$ ті прокидалися, Леля повертала пташок із вирію - $і$ ті своїм співом та радістю звеселяли світи, закликаючи добро й щастя в оселі» [12, с. 231].

Міфологема «Симаргл» корелює 3 жіночими образами як у традиційній міфологічній системі, так і в художніх текстових структурах. Але фемінні персонажі є різними. Так, у міфології Симаргл пов'язаний з образом богині Мокоші [8, с. 19], а в Дари Корній - з образом Ягілки. У романі «Зворотний бік світів» Симаргл - це крилатий собака, відданий друг Ягілки: «Пес, який зовнішньо дуже був схожий на вовка, мав крила» [11, с. 33]. Письменниця акцентує ще на одній важливій ознаці образу: «Симарал не просто спостерігач за часом, він теж частина часу» [11, с. 298].

Із-поміж маскулінних образів у художньому мовленні Дари Корній наведено ще й такі: Числобог - «володар часу» [11, с. 286]; Гай-бог «бог мисливства» [11, с. 100]; Чорнобог: «Сердитий дідуган, довга борода, голову закриває каптур, кривий посох у правій руиі, гора черепів у ногах, мурах, якісь птахи» [13, с. 57]; Переплут - світлий безсмертний [13, с. 316], Володар світу Безконечного Океану [12, с. 80]; Пал, який «запалював вогняні кулі з недобрим вогнем, які, потрапляючи на тіло, хоч і не пропалювали його, та робили вразливим» [12, с. 40], 
Повелитель вогню [13, с. 62]; Полель - покровитель шлюбу [12, с. 54]; Сон - сліпий старший син Мари та єдиний син Велеса [12, с. 226]; Посвист - Повелитель бурі [13, с. 62]; Редагаст - Повелитель війни $[13$, с. 62]; Припекало - Повелитель облуди і розпусти [13, с. 62]; Худіч Повелитель мук [13, с. 62] - «високий, мов жердина, довготелесий... Очі-провалля, чорні-пречорні, без білків. Його смоляне волосся жило власним життям, бо навіть коли чоловік перебував у повному спокої, воно хаотично ворушилося, змінюючи відтінок, зачіску» [13, с. 256]; Ніян - Повелитель покарань [13, с. 62].

Активним у маскулінній образній системі художнього мовлення Дари Корній є образ Морока, оскільки йому письменниця відводить роль дідуся головної героїні своєї казкової саги Мальви. Морок (або Мор) є Володарем темних [13, с. 230]. У його портреті домінує чорний колір: «Повелитель Морок, здогадалася Мальва. Чорне коротко стрижене волосся, чорна коротка борода, обличчя, помережене зморшками, чорні маленькі очі. Але не такі теплі, як у батька Стрибога. Навпаки, дошкульні та пекучі» [13, с. 60-61]. Його всі бояться, бо «Морок, який в Оселищі Відтіні є головним, вимагає від усіх послуху та дисциилліни...» $[13$, с. 59]. У художньому мовленні Дари Корній образ набуває іронічного відтінку: «Ото вже пихатий дідуган, який не впорався ні зі свойм сином, ні з онукою і який чомусь себе переконав, щуо це легше, аніж керувати Темним світом та долями мільйонів» [13, с. 292].

Дружиною Морока є Мара - «Повелителька Смерті та мати Стрибога» [13, с. 199]. У романах Дари Корній цей персонаж містить позитивну стилістичну маркованість: «Мара - ніжна, спокійна, завжди впевнена у собі, трішки меланхолійна...» [12, с. 76]. Грізна й страшна богиня постає в мовосвіті письменниці звичайною матір'ю: «Жінки сіли, і Мара почала розповідь. Говорила про свого чоловіка Морока-Мора і про сина Стрибога, і про те, як і чому вона пішла від них, і про те, що дуже втішилася, коли раптом ї̈ син покохав Птаху. Думала, щэо він зміниться й не перетвориться на свого батька. І він справді довго залишався нормальним. I Мара тоді дуже пишалася своїм сином, намагалася часто бувати поруч, коли мала час. Вона зараз говорила як любляча мати, а не жорстока та справедлива Повелителька Смерті, Володарка Перемінників» [13, с. 31]. Письменниця наділила свою героїню рисами, властивими звичайній смертній людині: «Мара низько схилила голову, і Птаха відчула вологість на своӥх руках. Мара плака- 
ла» [13, с. 32]; «Перед нею сиділа не та велична та поважна Мара, Володарка Смерті, яку вона завжди знала, поважала і навіть побоювалася. Зараз це була трохи знічена, втомлена виконаннями великого обов'язку, звичайна жінка. Так, чорні очі, як у сина, проте зовсім не холодні й без натяку на лукавинки, як у Стрибога, теплі, як повітря влітку, і трохи вологі, наче весняна земля після дощу» [13, с. 34].

Ще одним фемінним образом, добре виписаним у мовній канві художнього світу Дари Корній, є Яга-Ягілка. У романі «Зворотний бік світів» вона постає у двох іпостасях - і як красуня, і як потвора: «Buсока, красива, чимсь схожа на Птаху. Може, спокійною манерою вести розмову, некваплива й грачійна» [11, с. 29]; «Та найбільше вразила Мальву переміна в зовнішності Ягілки. Ніс довгий $і$ гачкуватий, очі банькаті та вицвілі майже до білого. Сиві пасма волосся стирчать 3-під чорного очіпка. Постать крива та згорблена. Улівій руиі Ягілки палка-кривулька, на яку вона опиралася, икутильгаючи. Ліва рука та ліва нога - кістяні» [11, с. 36-37]. Таке ії перевтілення пов'язане 3 функційною спрямованістю образу: «Ягілка-Яга - се хранитель межі, котра існує між світом живих і світом мертвих, між Явою й Навою. Це жінка, яка водночас і жива, і мертва. Однією ногою, із крові та полоті, вона поки щуо у світі живих, а іншою, кістяною, без плоті, вона може перебувати і по той бік життя. Вона провідник між світами» $[11$, c. 30]. Ягілка в мовосвіті Дари Корній - це донька Земун і Сварога. Ці біографічні відомості письменниця вкладає в уста своєї героїні: «I, випереджаючи твої запитання, скажу, що я не Земун. Мене звати Ягілка. Я ї̈ донька, наймолодша сестра сварожичів» [11, с. 76].

Авторка наводить і родовід Дзеванни: «Донька Миха, повелителя та опікуна лісових звірів, та прекрасної Діванни, повелительки плодючості» [11, с. 118]. Письменниця так описує образ Дзеванни: «Так, Дзеванна й справді талановита безсмертна. Вміння володіти мистецтвом полювання - то від батька Миха. Вона вправно читає мову слідів тварин та птахів, насліпо з лука бездоганно потрапляє в иіль, ножем легко вражає серие птаха на льоту чи будь-якого звіра в русі. У изьому їи рівних немає» [11, с. 120].

Представлені в ідіолекті Дари Корній міфологічні образи мають безпосередній зв'язок з об'єктами міфологічного світогляду давніх українців, але в канві художнього твору набувають виразних додаткових семантичних і стилістичних відтінків. 


\section{5. Фауністичні міфологічні образи}

Фауністичні образи, представлені в художньому мовленні Дари Корній, також перегукуються з давньоукраїнськими міфологічними персонажами. Одним із таких образів є змія. В. Войтович зазначає, що «давній культ змії простежується у віруванні про іiі роль в оволодінні знахарським мистецтвом. Кажуть: якби зловити білу гадюку та зібрати 3 неї отруту, то хто б перший покуштував тієї юшки з м'ясом, той знав би усе: як звірі розмовляють, як птахи, трави перешіптуються. Адже саме змії навчили людину пізнавати цілющі властивості рослин, розуміти мову квітів і трав» [4, с. 522]. Подібне тлумачення спостерігаємо й у романі «Зворотний бік світів», де в образі змії підкреслюється мудрість: «Та жінка врятувалася, в останній момент їй допомогла мудра змія, яка то все бачила» [11, с. 75].

Іншим поширеним фауністичним образом є вовк - «символ хижацтва, невгамовного голоду, швидкості» [4, с. 519]. Цей міфоконцепт корелює з міфологічним образом вовкулаки. Вовкулака узуально визначається як «людина, що обертається у вовка» [23, 1, с. 62]. Валерій Войтович твердить: «До кінця XIX ст. в українському та білоруському фольклорі активно побутували розповіді про вовкулаків. Про поширення таких оповідок у неврів - племені, яке в V ст. до н. е. населяло верхів'я Дніпра, згадував ще Геродот» [4, с. 80]. Цю особливість давньослов'янського міфологічного світогляду описала й Дара Корній: «Майже дві третіх чоловічої частини Невридї вміють перекидатися вовками» [11, с. 102]; «Це діти Невридї- звичайні смертні вовкулаки, оборонці входу у Милоград - головне поселення світу Білих Вурдалаків» [13, с. 163].

Одним 3 орнітологічних образів давньослов'янської міфології $\epsilon$ Жар-птиця - «чарівний вогнистий птах, який прилітає з тридесятого царства» [4, с. 172]. Дара Корній наділяє цей міфологічний персонаж магічними можливостями: «Випий. Це сльози Жар-Птиці. Зиілюють внутрішні рани від проклять. Зроби лишень три ковтки. Цього доcumb» $[11$, c. 175$]$.

Отже, лексико-семантична група фауністичних міфологем $\epsilon$ кількісно невеликою. Незважаючи на це, такі образи слугують важливим сегментом цілісної міфологічної концепції наших предків. 


\section{6. Інші персонажі міфологічного світогляду давніх українців}

Окремою групою міфологічної системи, описаної в романах Дари Корній, постають апелятивні назви на позначення істот. У творах письменниці вони є другорядними персонажами, про них авторка згадує в деяких контекстах, наприклад: «Безсило кружляли у темних небесах світлі гамаюни, алаканости, сіріни, рароги $і$ навіть жср-птиці, осліплені чорним вогнем чорного сония чорного світу» [12, с. 40]; «Puдає над тілом Дажбога Дана, плачуть сіріни та голосять гамаюни» [12, с. 43]; «I поки Майя з гостем пили нектар із квітів, вирощених y саду мелюзин, Оракул розплутував иңю справу» [12, с. 81]; «Сльози сіріна допомагають вернути до життя того, хто блукає сутінками Всесвіту» [12, с. 90]. Деякі номінації є онімними, як, скажімо, у контексті: «Нашу Західну браму, крім заклинань та оберегових знаків, охороняє Рарог, вогняний крилатий Сокіл. Правда, він мандрівник щее той. Сам з Райського саду, довго мешкав у світі Невидимих, а тепер от знайшов собі нове заняття - Воротар Західної брами. Північні та Південні ворота оберігають відповідно Триголовий та П'ятиголовий Змії, а изе просто ідеальні воротарі» [12, с. 192].

Цікавим фемінним міфообразом є русалки. Узуально вони трактуються як «богині земної води, які живуть на дні водоймищ» [4, с. 449]. Дара Корній наводить міфолексему «русалії», позначаючи нею предків русалок і водяників [11, с. 108]. Цих міфологічних персонажів письменниця описує так: «Прекрасні та дивні істоти. Зовні дуже схожі на людей. Принаймні від голови і до пояса - стовідсотково. А нижче? У них не було ніг. Замість нижніх кінцівок ті істоти мали риб'ячий хвіст. Такі собі риболюди» [11, с. 105]. У романі «Зворотний бік світів» авторка підкреслює амбівалентність образу русалій: вони могли зцілювати й могли погубити. Такою властивістю був наділений їхній спів: «Сniвали вони не завжди. Лишень уночі та в той час, коли місяць стояв уповні. То був иілюший спів. Він лікував усі душевні хвороби, включаючи відчай, божевілля, залежність та одержимість. I до тої річки часто приходили люди, переважно смертні, щзоб послухати спів русалій та зиілитися» [11, с. 105]. Згубну дію русалій авторка підкреслює в контексті: «... Вони так пестощами та любощами закохували чоловіка чи жінку, що ті помирали не в муках, а від задоволення» [11, с. 106].

I. Огієнко твердив, що, крім представників вищого рівня давньослов'янської міфології, існують духи. Вони «звичайно отримували 
збірну назву, а не одиничне ім'я, певне, тому, що їх було занадто багато» [16, с. 120]. Дослідник наполягав на зміні аксіологічної шкали цих міфоконцептів від позиції добра до відмітки зла: «Спочатку довколишні духи були добрими, але з бігом часу вони ставали злими, особливо деякі з них, що все пильнували дошкульно нашкодити» [16, с. 120]. У художньому мовленні Дари Корній наявний образ духу води, який маркується позитивно: «Зовсім поруч жебонів маленький струмок. Стала навколішки, попросила в духу води напитися. Вода радісно забулькала» [13, с. 284].

Отже, різноманітні міфічні істоти розширюють загальноконцептуальну міфологічну систему, а відповідні номінації збагачують аналізовану мікросистему лексичного складу української мови.

\section{7. Вербалізація предметів міфосвіту, наділених захисною функцісю}

І3-поміж номінацій на позначення предметів, які в міфологічній свідомості давніх українців наділені особливими властивостями, виділяється група назв міфоконцептів, які виконують захисну функцію. До них належать, насамперед, іменники «оберіг» та «амулет». Ширшим поняттям є оберіг. Це «невеличкий предмет, який носили при собі 3 охоронною метою» [4, с. 339].

У художньому мовленні Дари Корній обереги мають онімні або апелятивні найменування, наприклад: «Це оберіг. Вужсич. Символ зв'язку з предками. Він об'єднує теперішнє та майбутнє. Це иілісність єства людини: тіло, душа, дух та совість - одне» [13, с. 78]; «Мольинець. Один із символів батька Рода, - замепотів на вухо Остапу Мирослад. - Це обереговий символ. Неври впевнені, щуо якщо довкола нього зберуться з благими намірами в коло безсмертні, то це захистить їхніх світ на довгі літа від ворога явного та навіть невидимого. Бо ичей символ примножує силу молитви та благань у тисячу разів» [11, с. 87]; «Це молитвинець, великий дар батька Рода. Він береже від злого, недоброго слова, від проклять і замовлянь, від обмови, наклеnу і всіх потороч-втручань у серче, мозок та душу» [11, с. 265].

Різновидами оберегів $є$ наузи, нав'язи й амулети. В. Войтович визначає амулет як «невеличкий предмет-оберіг, талісман, який носили при собі» [4, с. 9]. Амулети наділені надзвичайними властивостями. Їхню різну функційну спрямованість підкреслює авторський текст: «Амулетами можна легко зневільнити навіть найсильнішого, якщо 
хитрістю переконати носити такий амулет. Збрехати, наприклад, щзо він додасть сили та допоможе бачити приховане» [11, с. 239]; «Відгородився від запахів, звуків реального і пірнув у світ Безконечного Океану за допомогою амулета - великого срібного кулона з красивим ажурним орнаментом $і$ зображенням вигравіруваного на ньому рівностороннього хреста» [12, с. 81].

Безпосередньо захисну функційну виконує ладанка. Традиційно вона тлумачиться як «мішечок з ладаном або якимсь талісманом, які віруючі носять на шиї разом 3 іншими оберегами від нещастя» [4, с. 273]. У мовосвіті Дари Корній теж є ладанка, яка «захищає, говорить правду, розпізнає брехню та зрадників» [11, с. 214]. Різновидом ладанки є сварга, яку носить на шиї Стрибог для впевненості у своїй непереможності та всемогутності [11, с. 221].

Захисним властивостями наділені деякі предмети з навколишнього середовища. Так, в ідіолекті української письменниці такими постають мушля, перстень і лялька. Мікрообраз мушлі в міфосвіті еволюціонував від захисної функції та символічної. Він $є$ позитивно маркованим, оскільки корелює зі Світом Білобога: «...Ця мушля ... з Біловоддя. Вона належала Зорині, останньому із великих правителів світу Сонячної Мушлі. I передавалася від правителя до правителя спочатку як оберіг, а потім як символ влади» [11, с. 251].

Захисну функцію виконує також перстень: «Та перстень ияей був дуже сильним оберегом для його власника. Ані стріла, ані меч, ані прокляття не брали його. Бо був замовлений на життя» [12, с. 138-139]. Захищати «від недоброго ока, злих намірів, лихих вчинків» [12, с. 137] повинна й лялька-мотанка.

Отже, довкілля містить предмети й речі, які наділяються магічними властивостями, несуть потужний емоційний заряд і $є$ надзвичайно важливими об'єктами міфологічного буття.

\section{8. Висновки}

Сучасна українська проза, зокрема романи Дари Корній, має глибинні зв'язки 3 давнім слов'янським світоглядом. Художні тексти на вербальному рівні передають міфологічні уявлення та вірування.

Твори Дари Корній відтворюють вищий і нижчий рівні давньоукраїнської міфології, охоплюють фауністичні, флористичні, архетипні образи, наділені надзвичайною силою предмети та речі. 
У міфообразах, які формують авторську канву художнього твору, простежуються глибинні зв'язки із світобаченням і світовідчуттям давньої людини. Письменниця вдало вплітає традиційні міфологічні об'єкти у власний мовосвіт, надає їм додаткових семантико-стилістичних відтінків. Усі світи, зображені авторкою, наповнені різноманітними міфологічними об'єктами, які набули яскравої вербалізації в художньому мовленні.

Перспективи подальшого дослідження вбачаємо в грунтовному мовознавчому аналізі розширеної системи міфологічних об'єктів язичницького світогляду давніх слов'ян на матеріалі творів сучасної української літератури.

\section{Список літератури:}

1. Афанасьев А. Н. Происхождение мифа. Статьи по фольклору, этнографии и мифологии. Москва : Индрик, 1996. 635 с.

2. Василенко А. М. Українська міфологічна лексика в художній літературі XIX ст. : дис. ... канд. філол. наук : 10.02.01 / Ніжинський державний педагогічний університет імені Миколи Гоголя. Ніжин, 2003. 223 с.

3. Виклади давньослов'янських легенд, або Міфологія. Укладена Я. Ф. Головацьким. Київ : Довіра. 1991. 92 с.

4. Войтович В. Українська міфологія. Київ : Либідь, 2005. - 663 с.

5. Гнатюк В. М. Нарис української міфології. Львів : Інститут народознавства НАНУ, 2000. 259 с.

6. Драгоманов М. П. Малорусские народные предания. Киев, 1876.

7. Записки о Южной Руси. Издаль П. Кулишъ. Санкт-Петербургъ : Въ Типографіи Александра Якобсона, 1856.354 с.

8. Иванов В. В., Топоров В. Н. Исследования в области славянских древностей: Лексические и фразеологические вопросы реконструкции текстов. Москва, 1974. 341 с.

9. Кобилянський Б. В. Східнокарпатські міфоніми. Мовознавство. 1980. № 1. C. 41-49.

10. Колесник Н. Фольклорна ономастика. Випуск 1. Теоретичний аспект. Чернівці : Рута, 2000. 39 с.

11. Корній Дара. Зворотний бік світів. Харків : Клуб сімейного дозвілля, 2016. 316 c.

12. Корній Дара. Зворотний бік сутіні. Харків : Клуб сімейного дозвілля, 2016. 284 с.

13. Корній Дара. Зворотний бік темряви. Харків : Клуб сімейного дозвілля, 2015. 316 c.

14. Костомаров М. І. Слов'янська міфологія. Київ : Либідь. 1994. 383 с.

15. Лукінова Т. Б. Давньослов'янські вірування в дзеркалі лексики слов'янських мов (до етимології слів упир, нетопир). Мовознавство. 1981. № 6. C. 59-68. 
16. Митрополит Іларіон. Дохристиянські вірування українського народу. Київ, 1992. 421 с.

17. Нечуй-Левицький I. С. Світогляд українського народу. Ескіз української міфології. Київ : Обереги, 1992. 87 с.

18. Павленко Ю. Дохристиянські вірування давнього населення України. Київ : Либідь, 2000. 323 с.

19. Подольская Н. В. Словарь русской ономастической терминологии. Москва : Наука, 1978. 198 с.

20. Потебня А. А. О некоторых символах в славянской народной поэзии. Харьков, 1914. С. 1-123.

21. Потебня А. А. Слово и миф. Москва, 1989. $623 \mathrm{c.}$

22. Рыбаков Б. А. Язычество древних славян. Москва : Наука, 1981. 606 с.

23. Словник української мови: в 11 т. / АН УРСР. Інститут мовознавства; за ред. І. К. Білодіда. - Київ : Наук. думка, 1970-1980.

24. Слухай (Молотаева) Н. В. Художественный образ в зеркале мифа этноса: М. Лермонтов, Т. Шевченко. Киев, 1995. 486 с.

25. Українська мова. Енциклопедія / В. М. Русанівський та ін. Київ : «Укр. енциклопедія» ім. М. П. Бажана, 2000. 750 с.

\section{References:}

1. Afanas'ev A. N. (1996). Proishozhdenie mifa. Stat'i po fol'kloru, jetnografii i mifologii [The origin of the myth. Articles about folklore, ethnography and mythology]. Moscow : Indrik, $635 \mathrm{pp}$.

2. Vasylenko A. M. (2003). Ukrayinska mifologichna leksyka v xudozhnij literaturi XIX st. : dys. ... kand. filol. nauk : 10.02.01 [Ukrainian mythological vocabulary in the literature of the 19th century]. Nizhyn, $223 \mathrm{pp}$.

3. Vyklady davnoslov'yanskyx legend, abo Mifologiya (1991). Ukladena Ya. F. Golovaczkym [The summary of ancient Slavic legends, or Mythology. Composed by J. F. Golovatsky]. Kyiv : Dovira, 92 pp.

4. Vojtovych V. (2005). Ukrayinska mifologiya [Ukrainian mythology]. Kyiv : Lybid, $663 \mathrm{pp}$.

5. Gnatyuk V. M. (2000). Narys ukrayinskoyi mifologiyi [The Ukrainian mythology essay]. Lviv : The Ethnology institute of the National Academy of sciences of Ukraine, $259 \mathrm{pp}$.

6. Dragomanov M. P. (1876). Malorusskie narodnye predanija [Malorusskij folk legends]. Kyiv.

7. Zapiski o Juzhnoj Rusi. (1856). Izdal P. Kulish [Notes of South Russia. Published by P. Kulish]. St. Petersburg : Typography of Alexander Jakobson, 354 pp.

8. Ivanov V. V., Toporov V. N. (1974). Issledovanija v oblasti slavjanskih drevnostej: Leksicheskie i frazeologicheskie voprosy rekonstrukcii tekstov [Slavic antiquities study: Lexical and phraseological issues of text reconstruction]. Moscow, $341 \mathrm{pp}$.

9. Kobylyanskyj B. V. (1980). Sxidnokarpatski mifonimy [East Carpathian myths]. Linguistics, no. 1, pp. 41-49.

10. Kolesnyk N. (2000). Folklorna onomastyka. Vypusk 1. Teoretychnyj aspekt. [Folk onomastics. Edition 1. Theoretical aspect]. Chernivtsi : Ruta, 39 pp. 


\section{Chapter «Philological sciences»}

11. Kornij Dara (2016). Zvorotnyj bik svitiv [The reverse side of the worlds]. Kharkiv : Family Leisure Club, 316 pp.

12. Kornij Dara (2016). Zvorotnyj bik sutini [The reverse side of twilight]. Kharkiv : Family Leisure Club, 284 pp.

13. Kornij Dara (2015). Zvorotnyj bik temryavy [The reverse side of darkness]. Kharkiv : Family Leisure Club, 316 pp.

14. Kostomarov M. I. (1994). Slov'yanska mifologiya [Slavic mythology]. Kyiv : Lybid. 383 pp.

15. Lukinova T. B. (1981). Davnoslov'yanski viruvannya v dzerkali leksyky slovyanskyx mov (do etymologiyi sliv upyr, netopyr) [Old Slavic beliefs in the mirror of the Slavic languages vocabulary (to the etymology of the words vampire, noctule)]. Linguistics, no. 6, pp. 59-68.

16. Mytropolyt Ilarion (1992). Doxrystyyanski viruvannya ukrayinskogo narodu [Pre-Christian beliefs of the Ukrainian people]. Kyiv, $421 \mathrm{pp.}$

17. Nechuj-Levyczkyj I. S. (1992). Svitoglyad ukrayinskogo narodu. Eskiz ukrayinskoyi mifologiyi [Worldview of the Ukrainian people. Sketch of Ukrainian mythology]. Kyiv : Oberegy, $87 \mathrm{pp}$.

18. Pavlenko Yu. (2000). Doxrystyyanski viruvannya davnogo naselennya Ukrayiny [The pre-Christian beliefs of the ancient locals of Ukraine]. Kyiv : Lybid, $323 \mathrm{pp}$.

19. Podol'skaja N. V. (1978). Slovar' russkoj onomasticheskoj terminologii [Dictionary of Russian onomastic terminology]. Moscow: Nauka, 198 pp.

20. Potebnja A. A. (1914). O nekotoryh simvolah v slavjanskoj narodnoj pojezii [About some symbols in Slavic folk poetry]. Kharkiv, p. 1-123.

21. Potebnja A. A. (1989). Slovo i mif [Word and myth]. Moscow, 623 pp.

22. Rybakov B. A. (1981). Jazychestvo drevnih slavjan [Paganism of the ancient Slavs]. Moscow : Nauka, 606 pp.

23. Slovnyk ukrayinskoyi movy: v 11 t. [Ukrainian language dictionary: in $11 \mathrm{v}$. / Academy of Sciences of the USSR. Institute of Linguistics; ed. by I. K. Bilodid]. Kyiv : Naukov dumka, 1970-1980.

24. Sluxaj (Molotaeva) N. V. (1995). Xudozhestvennыj obraz v zerkale myfa эtnosa: M. Lermontov, T. Shevchenko [Artistic image in the mirror of the ethnos myth]: Kiev, 486 pp.

25. Ukrayinska mova. Encyklopediya (2000). / V. M. Rusanivskyj ta in. [Ukrainian language. Encyclopaedia / V. M. Rusanivsky and others]. Kyiv : «Ukrainian encyclopaedia» M. P. Bazhan, 750 pp. 